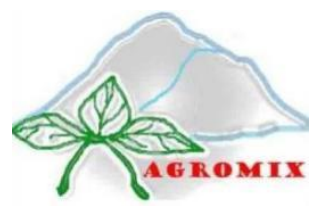

\title{
AGROMIX
}

Jurnal IImiah Fakultas Pertanian, Universitas Yudharta Pasuruan pISSN (Print): 2085-241X; elSSN (Online): 2599-3003

Website: https://jurnal.yudharta.ac.id/v2/index.php/agromix

\section{Mengembangkan skenario panen porang satu musim melalui manipulasi tanam lebih awal dan perlambatan waktu dorman fase generatif dengan pemberian asam salisilat organik alami di lahan kering Lombok Utara}

Developing a one-season porang harvest scenario through manipulation of early planting and slowing down the dormant period of the generative phase by giving natural organic salicylic acid in the dry land of North Lombok

\author{
Suparman ${ }^{1}$, Suwardji $^{2 *}$, Kusnarta IGM ${ }^{2}$, Sukartono ${ }^{2}$ \\ ${ }^{1}$ Program Studi Pertanian Ilmu Tanah, Universitas Mataram, Mataram, Indonesia \\ ${ }^{2}$ Program Studi Ilmu Tanah Fakultas Pertanian Universitas Mataram, Mataram, Indonesia \\ *Email korespondensi: suwardji@unram.ac.id
}

\section{Article History}

Received : July 19, 2021

Accepted : September 13, 2021

Published : September 28, 2021

Keywords:

Dormancy; Porang; Salicylates

\section{ABSTRACT}

The research on the scenario of one-season porang harvest through crop manipulation and delaying dormancy time aims to determine the effect of salicylic acid in breaking the dormancy of porang bulbil seeds during seeding and to determine the effect of slowing down the dormant period of the generative phase, so it is expected to be an alternative porang cultivation technology that is profitable for farmers The method used in this study used a completely randomized design experiment on breaking dormancy and a randomized block design in an experiment with slowing down the dormancy time of the generative phase with four salicylic acid concentrations $(0 \%, 0.5 \%, 1 \%$, and $2 \%)$ with eight replicates were planted under rainfed conditions. The results showed that the concentration of salicylic acid $(\mathrm{C} 7 \mathrm{H} 6 \mathrm{O} 3) 2 \%$ was the best treatment in increasing tuber weight $(52.25 \%)$ compared to the control. Application of Salicylic Acid $(2 \%)$ was significantly able to increase the vegetative growth of porang plants, which was shown by increasing plant height by $50.38 \%$ and breaking seed dormancy 14 days faster than the control (without the addition of Salicylic Acid). Furthermore, the delay in dormancy time occurred 1 month later than the control so that it could prolong the vegetative phase. The concentration of $2 \%$ salicylic acid is the best treatment, which can be recommended in the development of one-season porang cultivation technology that can increase farmers' profits.

\section{Riwayat Artikel \\ Dikirim : 19 Juli, 2021 \\ Disetujui : 13 September 2021 \\ Dipublis : 28 September 2021}

Kata Kunci:

Dormansi; Porang; Salisilat

\section{ABSTRAK}

Penelitian tentang skenario panen porang satu musim melalui manipulasi tanam dan perlambatan waktu dormansi bertujuan untuk mengetahui pengaruh asam salisilat dalam mematahkan dormansi benih bulbil porang saat pembibitan dan mengetahui pengaruh perlambatan waktu dorman fase generatif, sehingga diharapkan menjadi alternatif teknologi budidaya porang yang menguntungkan bagi petani. Metode yang digunakan dalam penelitian ini menggunakan percobaan Rancangan acak lengkap pada percobaan pematahan dormansi dan Rancangan acak kelompok pada percobaan perlambatan waktu dormansi fase generatif dengan empat perlakuan konsentrasi asam salisilat $(0 \%, 0,5 \%, 1 \%$, dan $2 \%)$ dengan delapan ulangan ditanam di bawah kondisi tadah hujan. Hasil penelitian menunjukkan bahwa konsentrasi asam salisilat $\left(\mathrm{C}_{7} \mathrm{H}_{6} \mathrm{O}_{3}\right) \quad 2 \%$ merupakan perlakuan terbaik dalam meningkatkan bobot umbi $(52,25 \%)$ dibandingkan dengan kontrol. Aplikasi Asam Salisilat $(2 \%)$ secara nyata mampu meningkatkan pertumbuhan vegetaif tanaman porang, yang ditunjukkan melalui peningkatan tinggi tanaman sebesar $50,38 \%$ dan pematahan dormansi benih 14 hari lebih cepat dibandingkan dengan kontrol (tanpa penambahan Asam Salisilat ). Selanjutnya, perlambatan waktu dormansi terjadi 1 bulan lebih lambat dibandingkan dengan kontrol sehingga dapat memperpanjang fase vegetatif. Konsentrasi asam salisilat $2 \%$ adalah perlakuan yang terbaik, yang dapat direkomendasikan dalam pengembangan teknologi budidaya porang satu musim yang dapat meningkatkan keuntungan petani.

Sitasi: Suparman, Suwardji, Kusnarta IGM, \& Sukartno. (2021). Mengembangkan skenario panen porang satu musim melalui manipulasi tanam lebih awal dan perlambatan waktu dorman fase generatif dengan pemberian asam salisilat organik alami di lahan kering Lombok Utara . Agromix, 12(1), 74-78. https://doi.org/10.35891/agx.v12i2.2596 


\section{PENDAHULUAN}

Tanaman porang (Amorphophallus muelleri Blume) adalah jenis tanaman umbi umbian yang termasuk dalam famili Araceae (Sari \& Suhartati, 2015). Tanaman ini mempunyai potensi dan prospek besar untuk dikembangkan di Indonesia karena permintaan ekspor yang terus meningkat (Puspitorini dkk., 2019). Selain mudah dibudidayakan, tanaman ini tidak memerlukan lahan khusus karena dapat tumbuh di bawah tegakan agroforestri bahkan pencampuran tanaman porang di bawah tergakan justru menghasilkan pertumbuhan terbaik (Purnamasari, 2012). Di wilayah lahan kering khususnya Lombok Utara tumbuhan porang ini banyak ditemukan di hutan-hutan. Umbi porang awalnya diambil secara liar dari dalam hutan. Sekitar tahun 1990, porang mulai dibudidayakan karena tanaman ini memiliki nilai ekonomi yang tinggi dan permintaan pasar yang terus meningkat baik dalam bentuk segar maupun chip kering (Utami, 2021).

Tanaman porang mempunyai tiga siklus pertumbuhan yaitu periode vegetatif, generatif dan dorman dalam setiap periode tumbuh setiap tahunnya (Ganjari \& Eladisa, 2014). Pola pertumbuhan porang dari bibit biji bulbil, bibit umbi, dan bibit bunga hingga tanaman berbunga dan menghasilkan umbi yang optimal dalam sistem alami memerlukan waktu tiga sampai empat tahun atau tiga sampai empat periode tumbuh dan dorman. Pada musim kemarau tanaman porang akan mengalami dorman yang ditandai degan daun yang layu dan kering (Rahayuningsih, 2021). Setiap siklus tumbuh dan generatif terjadi selama waktu 5-6 bulan dan demikian juga pada periode dormannya memerlukan waktu 5-6 bulan (Indriyani dkk., 2011).

Dari kondisi siklus tersebut menunjukkan bahwa dalam budidaya porang mulai dari saat musim penghujan mulai menanam porang sampai waktu doman terjadi selama 5-6 bulan (Elvira dkk., 2020). Untuk kasus curah hujan di Pulau Lombok yang saat tanam mulai bulan Nopember sampai saat dorman bulan Maret memerlukan waktu lebih lama 2-3 siklus untuk dapat panen umbi porang dalam kondisi produksi yang optimal. Jika masa tumbuh ini dapat diatur lebih panjang (dormansi diperlambat) maka dimungkinkan memperoleh hasil umbi yang lebih berat per musimnya. Untuk itu maka perlu diupayakan cara memperpanjang masa tumbuh porang. Hal ini didukung oleh hasil temuan Sangket dan Saravanan (2017) pada tanaman umbi kaki gajah dengan penyemprotan asam salisilat dapat menghasilkan umbi yang maksimum selama 2 periode pertumbuhan. Asam salisilat berpotensi digunakan sebagai bahan untuk memperpanjang tumbuh atau mempersingkat masa dormansi porang (Suwardji, 2020). Akan tetapi belum ada penelitian terhadap takaran pemberian bahan tersebut, sehingga penelitian ini menjadi sangat penting untuk dilakukan.

\section{METODE}

\section{Alat dan bahan}

Alat-alat yang digunakan dalam penelitian ini adalah timbangan analitik, gelas kimia, gelas ukur, pipet, label, kertas saring, erlenmeyer, labu ukur, tabung kaca, evaporator, spektrofotometer. Bahan yang digunakan adalah asam salisilat, etanol pa, sampel tanah, bibit bulbil porang ukuran super ( $9 \mathrm{~g}$ ), aquades dan air hujan.

\section{Tempat pelaksanaan}

Percobaan dilakukan di lahan kelompok tani porang maju terus di Dusun Torean Desa Loloan Kecamatan Bayan, Kabupaten Lombok Utara yang sekaligus menjadi action research ditingkat hamparan petani. Penelitian ini dilaksanakan pada bulan September 2020 sampai dengan Mei 2021.

\section{Metode yang digunakan}

Metode yang digunakan dalam penelitian ini menggunakan percobaan Rancangan acak lengkap pada percobaan pematahan dormansi dan rancangan acak kelompok pada percobaan perlambatan waktu dormansi fase generatif dengan empat perlakuan konsentrasi asam salisilat (0\%, 0,5\%, 1\%, dan 2\%) dengan delapan ulangan ditanam di bawah kondisi tadah hujan. Penelitian lapangan dimulai saat musim penghujan menggunakan percobaan Rancangan Acak Kelompok dengan empat perlakuan konsentrasi asam salisilat generatif $(0 \%, 0,5 \%$, $1 \%$, dan $2 \%)$ dengan delapan ulangan ditanam di bawah kondisi tadah hujan. Bibit bulbil porang ukuran super (9 g) yang menjadi sasaran empat perlakuan penyemprotan daun yang berbeda (1) penyemprotan asam salisilat dengan konsentrasi 0\% (2) penyemprotan asam salisilat dengan konsentrasi $0,5 \%$ (3) penyemprotan asam salisilat dengan konsentrasi $1 \%$ (4) penyemprotan asam salisilat dengan konsentrasi $2 \%$ selama 1-2 bulan.

\section{Analisa data}

Semua data hasil pengamatan telah dianalisis menggunakan Analysis of Variance (ANOVA) dengan Program Costat 12.1. Apabila hasil ANOVA berbeda nyata, maka dilanjutkan dengan uji beda nyata jujur (BNJ) pada taraf $5 \%$. 


\section{HASIL DAN PEMBAHASAN}

\section{Pematahan dormansi pada benih katak/bulbil porang}

Tabel 1. Waktu pematahan dormansi katak/ bulbil porang

\begin{tabular}{ccccccc}
\hline \multicolumn{7}{c}{ Pengamatan hari ke } \\
\hline Konsentrasi SA (\%) & H0 & H7 & H14 & H28 & H42 & H56 \\
\hline 0 & - & - & - & - & $\checkmark$ & $\checkmark$ \\
0,5 & - & - & - & $\checkmark$ & $\checkmark$ & $\checkmark$ \\
1 & - & - & - & $\checkmark$ & $\checkmark$ & $\checkmark$ \\
\hline
\end{tabular}

Ketarangan :( $($ ) tunas tumbuh/dormansi patah 80\%, (-) belum muncul tunas $80 \%$

Tabel 1. Menunjukkan waktu yang dibutuhkan oleh bibit katak/ bulbil tanaman porang untuk mengalami pematahan dormansi (tumbuh tunas) setelah diberikan perlakuan asam salisilat dengan konsentrasi $2 \%$ menyebabkan pematahan dormansi bulbil paling cepat yaitu pada hari ke-14 setelah aplikasi untuk semua sampel. Sementara itu, asam salisilat dengan konsentrasi $0 \%$ (tanpa salisilat) yang diaplikasikan berhasil mematahkan dormansi bulbil pada hari ke-56, artinya bahwa perlakuan asam salisilat dengan konsentrasi $2 \%$ dapat mematahkan dormansi lebih cepat yaitu satu setengah bulan dibandingkan dengan perlakuan kontrol (tanpa salisilat). Bulbil/katak porang, masa dormansinya dapat dipatahkan selama kurang dari satu bulan atau sekitar 14 hari dengan pengaplikasian asam salisilat konsentrasi $2 \%$, hasil ini juga sejalan dengan hasil penelitian Suwardji (2020), yang mematahkan dormansi bibit dari bulbil ataupun umbi porang dengan mengaplikasikan ekstrak asam salisilat 0,2 \% dalam waktu 2-3 bulan setelah pengaplikasian.

Saefudin dkk. (2021) melaporkan bahwa salah satu upaya untuk mematahkan dormansi benih porang adalah dengan perendaman. Perendaman Asam salisilat sendiri pada benih porang berperan dalam mengurangi tekanan abiotik seperti kekeringan, dingin, panas, dan stress osmotik yang menyebabkan akumulasi ABA dan IAA dan selanjutnya memberikan pengaruh nyata terhadap pemecahan dormansi benih. SA juga memainkan peran penting dalam regulasi berbagai proses fisiologis dan biokimia selama seluruh umur tanaman (Vicente \& Plasencia, 2011).

Tinggi tanaman porang

Tabel 2. Tinggi tanaman porang pada berbagai konsentrasi asam salisilat

\begin{tabular}{ccccc}
\hline Konsentrasi SA & \multicolumn{4}{c}{ Tinggi tanaman porang $(\mathrm{cm})$} \\
\cline { 2 - 5 }$(\%)$ & $14 \mathrm{HST}$ & $28 \mathrm{HST}$ & $42 \mathrm{HST}$ & $56 \mathrm{HST}$ \\
\hline 0 & $20,92 \mathrm{c}$ & $24,54 \mathrm{~d}$ & $32,73 \mathrm{~d}$ & $35,49 \mathrm{~d}$ \\
0,5 & $22,79 \mathrm{c}$ & $28,38 \mathrm{c}$ & $38,54 \mathrm{c}$ & $44,65 \mathrm{c}$ \\
1 & $27,35 \mathrm{~b}$ & $34,92 \mathrm{~b}$ & $45,08 \mathrm{~b}$ & $48,23 \mathrm{~b}$ \\
2 & $32,06 \mathrm{a}$ & $41,40 \mathrm{a}$ & $49,21 \mathrm{a}$ & $53,25 \mathrm{a}$ \\
\hline BNJ & 1,97 & 1,96 & 2,28 & 2,48
\end{tabular}

Keterangan: Angka pada kolom yang sama diikuti oleh huruf yang tidak sama dinyatakan berbeda nyata dengan uji lanjut bnj pada taraf nyata $5 \%$.

Tabel 2. Menunjukkan tinggi tanaman porang. Perlakuan yang memberikan nilai paling tinggi adalah asam salisilat (SA) $2 \%$, diikuti oleh asam salisilat dengan konsentrasi $1 \%, 0,5 \%$, dan $0 \%$. Perlakuan asam salisilat $2 \%$ memberikan hasil yang berbeda nyata dengan setiap perlakuan lainnya. Asam salisilat (2\%) menyebabkan peningkatan yang signifikan dalam vegetatif, pertumbuhan tinggi tanaman porang meningkat $(50,38 \%)$ dibandingkan dengan perlakuan kontrol (tanpa salisilat).

Asam salisilat berperan penting dalam menginduksi ketahanan tanaman terhadap patogen yang selanjutnya dapat memperlancar keberlangsungan pertumbuhan vegetatif tanaman (Leiwakabessy dkk., 2017). Sangket dan Saravanan (2017) menjelaskan bahwa pengaplikasian asam salisilat (0,2 \%) menyebabkan peningkatan yang signifikan dalam pertumbuhan vegetatif. Primandani (2019) juga menjelaskan bahwa asam salisilat berpengaruh dalam membantu pertumbuhan vegetatif tanaman. Hal ini disebabkan karena kemampuan asam salisilat dalam mengurangi tekanan stres panas. Pada saat tanaman mengalami cekaman panas dan kekeringan, maka secara fisologi stomata akan menutup dan proses fotosintesis dibatasi (Hidayati dkk., 2017). Dengan pengaplikasian asam salisilat, maka cekaman dapat diatasi, dan selanjutnya akan meningkatkan laju fotosintesis yang secara langsung meningkatkan laju pertumbuhan tanaman porang (Laily dkk., 2018). 


\section{Perlambatan waktu dormansi}

Tabel 3. Perlambatan waktu dormansi tanaman porang

\begin{tabular}{cccccccc}
\hline \multirow{2}{*}{ Konsentrasi SA (\%) } & \multicolumn{7}{c}{ Perlambatan waktu dormansi (Hst) } \\
\cline { 2 - 8 } & 114 & 121 & 128 & 135 & 142 & 149 & 156 \\
\hline 0 & - & - & $\checkmark$ & $\checkmark$ & $\checkmark$ & $\checkmark$ & $\checkmark$ \\
0,5 & - & - & $\checkmark$ & $\checkmark$ & $\checkmark$ & $\checkmark$ \\
2 & - & - & - & - & $\checkmark$ & $\checkmark$ & $\checkmark$ \\
Waktu & - & - & - & - & - & Mei & $16 \mathrm{Mei}$ \\
\hline
\end{tabular}

Ketarangan : ( $)$ tanaman porang mati $80 \%$ (dorman) (-) belum dorman $80 \%$

Tabel 3. Menunjukkan waktu perlambatan waktu dormansi tanaman porang. Pengaplikasian asam salisilat pada tanaman porang dilakukan pada umur 107 HST. Pada pengaplikasian asam salisilat dengan konsentrasi yang berbeda akan memperlambat dormansi tanaman dalam jangka waktu yang berbeda pula. Pengaplikasian asam salisilat konsentrasi $0 \%$ (kontrol) atau secara konvensional masa pertumbuhan porang hanya sampai 6 bulan. Sementara perlakuan asam salisilat $2 \%$ mengalami penundaan dormansi selama 1 bulan lebih lama dibandingkan dengan perlakuan kontrol. Jika dikalkulasikan dari awal tanam (manipulasi tanam bulan September) maka tanaman porang dengan konsentrasi $2 \%$ bisa tumbuh sampai delapan setengah bulan. Ini berarti, perlakuan asam salisilat (SA) dengan konsentrasi $2 \%$ dapat memperlambat dormansi dengan selisih 1 bulan. Selisih 1 bulan ini diyakini kesempatan pengisian umbi pada tanaman yang diaplikasikan asam salisilat $2 \%$ menjadi lebih tinggi dibandingkan dengan SA $0 \%$. Hal ini selanjutnya akan menyebabkan bobot umbi tanaman porang secara total akan meningkat secara signifikan (tabel 4).

\section{Bobot umbi porang}

Tabel 4. Bobot umbi tanaman porang (t/ha) pada satu periode tanam

\begin{tabular}{cccc}
\hline Konsentrasi SA (\%) & Bobot umbi (t/ha) \\
\hline 0 & $2,22 \mathrm{~b}$ & \\
0,5 & $2,61 \mathrm{~b}$ & \\
1 & $3,31 \mathrm{a}$ & \\
2 & $3,38 \mathrm{a}$ & \\
\hline BNJ & 0,36 & & \\
\hline Keterangan: Angka pada kolom yang sama diikuti oleh huruf yang tidak sama menyatakan \\
berbeda nyata dengan uji lanjut BNJ huruf nyata 5\%.
\end{tabular}

Tabel 4. Menunjukkan bobot umbi porang (t/ha) yang didapatkan dalam 1 periode tanam (8,5 bulan). Hasil penelitian menunjukkan bahwa konsentrasi asam salisilat $\left(\mathrm{C}_{7} \mathrm{H}_{6} \mathrm{O}_{3}\right) 2 \%$ merupakan perlakuan terbaik dalam meningkatkan bobot umbi $(52,25 \%)$ dibandingkan dengan kontrol. Bobot umbi pada tanaman yang telah diaplikasikan salam salisilat $2 \%$ berbeda nyata dengan semua perlakuan lainnya (gambar 1 ). Dormansi porang yang terjadi pada musim kemarau, (cekaman kekeringan) akan menyebabkan tidak adanya peningkatan bobot umbi karena sudah memasuki fase istirahat dan dorman 3-4 bulan setelah dipanen (Muthuraj dkk., 2016; Nasrudin, \& Firmansyah, 2020). Cekaman kekeringan akibat dari penyiraman yang jarang akan mengurangi hasil umbi dan memaksa umbi untuk memasuki masa dormansi. Namun dengan pengaplikasian asam salisilat yang berperan dalam mengatasi cekaman kekeringan, maka masa dormansi akan diperlambat. Pada selisih waktu tersebut, kegiatan fotosintesis akan tetap terjadi, dan translokasi fotosintat ke umbi akan tetap berlangsung, yang menjadikan bobot umbi meningkat.

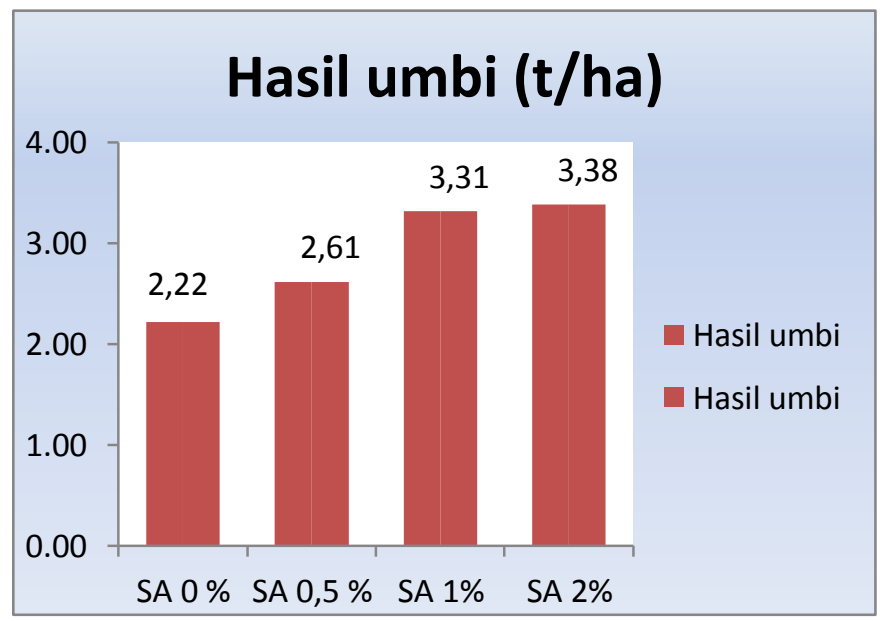

Gambar 1. Bobot umbi tanaman porang pada pengaplikasian SA dengan kosentrasi yang berbeda 
Pada gambar 1. Menunjukkan bahwa hasil umbi pada tanaman porang tertinggi pada pengaplikasian SA $2 \%$, kemudian dilanjutkan dengan hasil pada pengaplikasian SA 1\% dibandingkan dengan perlakuan kontrol. Hasil umbi ini membuktikan bahwa asam salisilat (SA) $2 \%$ memiliki pengaruh signifikan dalam pembesaran bobot umbi porang sehingga dapat meningkatkan hasil produksi yang lebih tinggi. Dari hasil umbi tertinggi tersebut dimungkinkan terjadi karena pengaruh perlambatan waktu dorman pada tanaman porang oleh perlakuan asam salisilat (SA) $2 \%$ sehingga terdapat waktu yang lebih lama untuk tanaman porang dalam memperbesar bobot umbi.

\section{KESIMPULAN}

Hasil penelitian ini menunjukkan bahwa perlakuan asam salisilat pada konsentrasi $2 \%$ mampu mematahkan masa dormansi benih 2 bulan lebih cepat dari perlakuan yang lain ( $0 \%, 1 \%$ dan 0,5\%) dan diikuti oleh perlambatan dormansi (perpanjangan masa tumbuh) yang paling lama terjadi pada tanaman yang disemprot asam salisilat konsentrasi $2 \%$ dengan selisih 1 bulan.

\section{UCAPAN TERIMA KASIH}

Ucapan terimakasih disampaikan kepada PT indofood Sukses Makmur Tbk. yang mensponsori penelitian ini dalam rangka Program Indofood Riset Nugraha 2020-2021.

\section{DAFTAR PUSTAKA}

Elvira, A. A., Hindarti, S., \& Khoiriyah, N. (2020). Usahatani porang dan kontribusinya terhadap pendapatan keluarga (study kasus: di Desa Selur, kecamatan Ngrayun, kabupaten Ponorogo). Jurnal Sosial Ekonomi Pertanian dan Agribisnis, 8(3), 113-123.

Ganjari, \& Eladisa, L. (2014). Pembibitan tanaman porang (Amorphophallus muelleri Blume) dengan model agroekosistem botol plastik. Widya Warta, 38(1), 45-58.

Hidayati, N., Hendrati, R. L., Triani, A., \& Sudjino, S. (2017). Pengaruh kekeringan terhadap pertumbuhan dan perkembangan tanaman nyamplung (Callophylum inophyllum L.) dan johar Cassia florida Vahl) dari provenan yang berbeda. Jurnal Pemuliaan Tanaman Hutan, 11(2), 99-111.

Indriyani, S., Arisoesilaningsih, E., Wardiyati, T., \& Purnobasuki, H. (2011). A model of relationship between climate and soil factors related to oxalate content in porang (Amorphophallus muelleri Blume) corm. Biodiversitas Journal of Biological Diversity, 12(1). https://doi.org/10.13057/biodiv/d120109

Laily, A., Hasanah, L., \& Irmansyah, T. (2018). Respon pertumbuhan dan produksi kedelai (Glycine max (L) Merril) terhadap perlakuan cekaman kekeringan dan pemberian antioksidan asam salisilat dan asam askorbat. Jurnal Online Agroekoteknologi, 6(1), 174-179.

Leiwakabessy, C., Sinaga, M. S., Mutaqin, K. H., Trikoesoemaningtyas, T., \& Giyanto, G. (2018). Asam salisilat sebagai penginduksi ketahanan tanaman padi terhadap penyakit hawar daun bakteri. Jurnal Fitopatologi Indonesia, 13(6), 207-207. https://doi.org/10.14692/jfi.13.6.207

Muthuraj, R., George, J., \& Sunitha, S. (2017). Effect of growth regulator and chemical treatment on dormancy breaking in elephant foot yam (Amorphophallus paeoniifolius (Dennst.) Nicolson). Journal of Root Crops, 42(2), 7580.

Nasrudin, N., \& Firmansyah, E. (2020). Respon pertumbuhan vegetatif padi varietas IPB 4S pada kondisi cekaman kekeringan. Agromix, 11(2), 218-226. https://doi.org/10.35891/agx.v11i2.2066

Primandani, D. (2019). Efek kombinasi ga3 dan asam salisilat terhadap perkecmbahan dan pertumbuhan kecambah pada kacang tanah (Arachis hypogaea L) Kultivar kelinci di bawah cekaman aluminium [Tugas Akhir, Universitas Lampung]. http://digilib.unila.ac.id/58381/

Purnamasari, U. (2012). Agroforestri porang masa depan hutan jawa. Fakultas Kehutanan UGM.

Rahayuningsih, Y. (2021). Analisis usahatani porang (Amorphophalus muelleri) di kecamatan Mancak, Kabupaten Serang, provinsi Banten. Jurnal Kebijakan Pembangunan Daerah, 5(1), 47-56. https://doi.org/10.37950/jkpd.v5i1.119

Saefudin, S., Syakir, M., Sakiroh, S., \& Herman, M. (2021). Pengaruh bobot dan perendaman bulbil terhadap viabilitas dan pertumbuhanporang (Amorphophallus muelleri Blume). Tanaman Industri Dan Penyegar, 8(2), 79-86.

Sangket, J., \& Saravanan, R. (2017). Management of heat stress to enhance growth, photosynthesis and corm yield of elephant foot yam (Amorphophallus paeoniifolius (Dennst.)). Scientia Agriculturae, 19(2), 47-54. https://doi.org/10.15192/PSCP.SA.2017.19.2.4754

Sari, R., \& Suhartati, S. (2015). Tumbuhan porang: prospek budidaya sebagai salah satu sistem agroforestry. Buletin Eboni, 12(2), 1-14. https://doi.org/10.20886/buleboni.5061

Puspitorini, P. S., Cahyono, P. A., \& Admiral, E. (2019). Pemberdayaan masyarakat jembul dengan teknologi tepat guna pengolahan chips porang dalam meningkatkan daya saing. International Journal of Community Service Learning, 3(4), 244-251. http://dx.doi.org/10.23887/ijcsl.v3i4.15723 
Suwardji. (2020). Mungkinkah mengembangkan sekenario budidaya porang satu musim: mensiasati pembibitan awal dan memperlambat terjadinya dorman dalam fase generatif. Webinar Budidaya Porang Perkumpulan Petani Porang Nusantara. Universitas Mataram.

Utami, W. A. (2021). Prospek ekonomi pengembangan tanaman porang di masa pandemi covid-19. Viabel Pertanian, 15(1), 72-82.

Vicente, M. R., \& Plasencia, J. (2011). Salicylic acid beyond defence: its role in plant growth and development. Exp Bot, 62(10), 3321- 3338. https://doi.org/10.1093/jxb/err031 